\title{
Rebamipide ophthalmic suspension for the treatment of dry eye syndrome: a critical appraisal
}

\author{
This article was published in the following Dove Press journal: \\ Clinical Ophthalmology \\ 30 May 2014 \\ Number of times this article has been viewed
}

\author{
Tomoyuki Kashima' \\ Hirotaka Itakura',2 \\ Hideo Akiyama' \\ Shoji Kishi' \\ 'Department of Ophthalmology, \\ Gunma University, School of Medicine, \\ Maebashi, Gunma, Japan; ${ }^{2}$ Department \\ of Ophthalmology, Maebashi Red \\ Cross Hospital, Maebashi, \\ Gunma, Japan
}

\begin{abstract}
Rebamipide was initially developed and approved for use in treating gastric ulcers and lesions associated with gastritis. Discovery of its ability to increase gastric mucin led to investigations of its effect on ocular surface mucin and the subsequent development for use in dry eye patients. Investigations have confirmed that rebamipide increases corneal and conjunctival mucin-like substances along with improving corneal and conjunctival injury. Clinically, rebamipide ophthalmic suspensions can effectively treat tear deficiency and mucin-caused corneal epithelial damage, and can restore the microstructure responsible for tear stability. Topical rebamipide has also been shown to be effective in treating other ocular surface disorders such as lagophthalmos, lid wiper epitheliopathy, and persistent corneal erosion. Rebamipide's ability to modify epithelial cell function, improve tear stability, and suppress inflammation in the absence of any known major side effects suggest that it may be a beneficial first drug of choice for severe dry eye treatment and other ocular surface disorders. This review summarizes the history and development of this innovative dry eye treatment from its initial use as an effective stomach medication to its current use in the treatment of dry eye in Japan.
\end{abstract}

Keywords: quinolinone derivative, tear deficiency, ocular surface disorder, mucin secretion, Mucosta

\section{History}

Rebamipide is a novel quinolinone derivative synthesized and developed by Otsuka Pharmaceutical Company, Limited (Tokyo, Japan) (Figure 1). After its initial discovery, it was used as an agent that promoted the healing of lesions in an experimental rat gastric ulcer model. ${ }^{1,2}$ Subsequently, in 1990, it was marketed as the Mucosta ${ }^{\circledR}$ tablet (Otsuka Pharmaceutical Company, Limited) for gastric ulcer therapy. ${ }^{3}$ Rebamipide has been shown to increase gastric endogenous prostaglandin $\mathrm{E}_{2}$ and $\mathrm{I}_{2}$, promote gastric epithelial mucin, ${ }^{1,4}$ behave as an oxygen free radical scavenger, ${ }^{5,6}$ and it has other anti-inflammatory actions..$^{7-10}$ In addition to its use for the gastrointestinal mucosa, the biological effects of rebamipide, which include cytoprotection, wound healing, and antiinflammatory properties, are known to be universal for a variety of tissues. ${ }^{10}$ In 1994 , gastric mucosal lesions (erosion, hemorrhage, erythema, and edema) associated with gastritis were subsequently added to its indications. ${ }^{11}$ Since then, it has been widely used as a therapeutic agent for gastritis and gastric ulcers. ${ }^{12}$ The clinical effectiveness of rebamipide for the treatment of stomatitis; ${ }^{13}$ pulmonary, ${ }^{14}$ renal, ${ }^{15}$ and liver damage ${ }^{16}$ colitis; ${ }^{17}$ and corneal protection ${ }^{18}$ has been demonstrated by both basic and clinical research. ${ }^{10}$ This drug also accelerated the healing of experimental gastric ulcers in Mongolian gerbils infected with Helicobacter pylori by improving cell kinetics, reducing apoptosis, and reducing inflammation. ${ }^{19}$

After discovering that the pharmacological actions of rebamipide included increasing gastric mucus (mucin), its development for use as a dry eye medication began with
Correspondence:Tomoyuki Kashima Department of Ophthalmology, School of Medicine, Gunma University, 3-39-I5 Showamachi, Maebashi, Gunma, Japan, 37I0034

Email kasimatomoyuki@yahoo.co.jp 


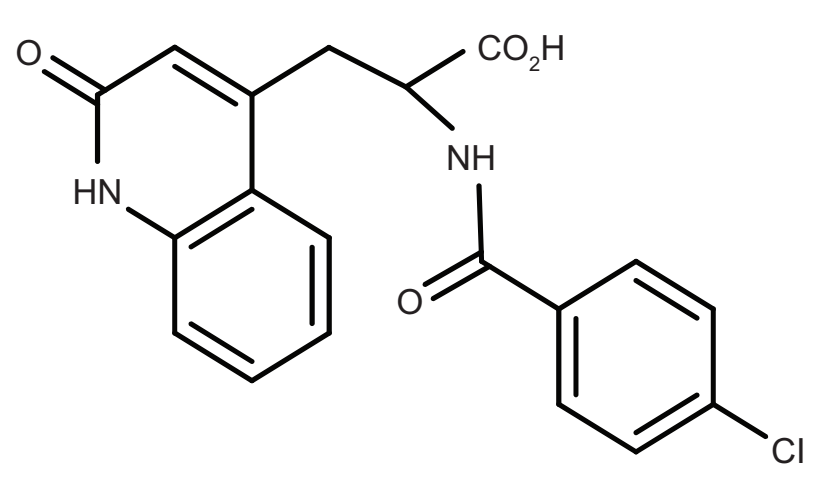

Figure I Structure of rebamipide.

investigations of its effect on the ocular surface mucin. ${ }^{1,4,20}$ In nonclinical studies, it was confirmed that rebamipide increased corneal and conjunctival mucin, and that it increased the conjunctival goblet cells in rabbits. ${ }^{21,22}$ The therapeutic effects of rebamipide are due to its ability to increase corneal and conjunctival mucin-like substances, and to improve corneal and conjunctival injury in vivo. ${ }^{18}$ It is known that rebamipide increases the mucin production in cultured conjunctival goblet cells $\mathrm{s}^{23,24}$ and in corneal epithelial cells. ${ }^{25}$ These reports additionally indicated that rebamipide increased the secretion of both membrane-associated and secreted-type mucins.

Clinical studies have shown that rebamipide has an improving effect not only on both corneal and conjunctivital epithelial damage, but also on subjective symptoms. ${ }^{26-28}$ Based on these results, rebamipide was launched in January 2012 for the treatment of dry eye in Japan (Mucosta ophthalmic suspension unit dose 2\%). In this paper, we review the published data and current usage of this innovative drug developed from a preexisting effective stomach medication that essentially has few side effects.

\section{Mechanism of action for gastric mucosa}

The pharmacological action of rebamipide for gastric mucosal injury is roughly divided into an action related to the protection of the gastric mucosa, which promotes healing of the mucosal injury, and actions related to anti-inflammation and the suppression of free radicals. ${ }^{29-32}$

A dose-dependent increase in prostaglandin $\mathrm{E}_{2}$ in the gastric mucosa was observed for rebamipide when it was intraperitoneally administered to rats. ${ }^{1}$ Rebamipide also increased the biosynthetic enzyme activity of the mucosal macromolecular glycoprotein and increased the amount of soluble gastric mucus in rats. ${ }^{33}$

In terms of the effect on free radicals, rebamipide was shown by electron spin resonance to scavenge hydroxyl radicals, which are very harmful reactive oxygen species that cause cell injury and lipid peroxidation. ${ }^{6}$ In rat neutrophils, rebamipide inhibits superoxide production induced by formyl-methionyl-leucyl-phenylalanine, a membrane receptor stimulator. ${ }^{34}$

The anti-inflammatory effects of rebamipide include a suppressive action on the infiltration of inflammatory cells into the gastric mucosa and on inflammatory cytokines. ${ }^{35}$ Rebamipide has been shown to inhibit increased interleukin (IL)-8 production induced by $H$. pylori irritation in cultured gastric cancer cells, which are derived from the gastric mucosa epithelium. ${ }^{36}$ In addition, rebamipide inhibited gastric mucosal injury and myeloperoxidase activity, which serves as an indicator of the infiltration of neutrophils across the gastric mucosa in an indomethacininduced ulcer model. ${ }^{37,38}$ In an ischemia-reperfusion model, rebamipide inhibited mucosal injury and myeloperoxidase activity in the gastric mucosa. ${ }^{38}$ These effects are related to the concentration of rebamipide in the gastric mucosa, which results from local penetration, as the blood levels and systemic distribution of rebamipide were shown to have little effect on its antioxidative and antineutrophilic activities. $^{39}$

\section{Therapeutic effect on gastric ulcers and gastritis}

Rebamipide promoted the healing of a gastric mucosal injury in a rat acetic acid ulcer model. ${ }^{2}$ Recurrence of gastric mucosal injury was shown to be inhibited by the administration of rebamipide in the chronic ulcer model. ${ }^{40}$ When subjective and objective symptoms were examined in human subjects, the improvement rate for patients with marked or moderate improvement was found to be $76 \% .{ }^{41}$ Follow-up of cases that were healed after the administration of rebamipide showed that there was a very low recurrence rate of a gastric mucosal injury of $6 \% .{ }^{41}$ An investigation of the efficacy of gastritis caused by non-steroidal anti-inflammatory drugs in healthy individuals demonstrated that rebamipide significantly inhibited gastric mucosal injury, erosion, and hemorrhage induced by indomethacin. ${ }^{42}$ Rebamipide has also been shown to contribute to the healing of artificial ulcers induced by endoscopic submucosal dissection for early-stage gastric cancer. $^{43,44}$

\section{Corneal and conjunctival mucin}

Mucin on the ocular surface is divided into membraneassociated mucins (MUC1, MUC4, MUC16), which are expressed on the apical surface of the corneal and 
conjunctival epithelia, and the secreted-type mucin (MUC5AC), which is produced by conjunctival goblet cells and released into the tear fluid..$^{21,45,46}$ Membrane-associated mucins serve as a barrier by preventing contact with pathogens and foreign substances on the corneal surface. They also play an important role in improving the lubricating property of the corneal surface. ${ }^{45,46}$ The secreted-type mucin contributes to the stability of tear fluid by interacting with the membrane-associated mucin. ${ }^{45,46}$

With regard to its effect on membrane-associated mucin, rebamipide upregulates the gene expression of $M U C 1, M U C 4$, and $M U C 16$, in addition to increasing the expression of protein in the cultured human corneal epithelial cells. ${ }^{47}$ For the secreted-type mucin, the amount of MUC5AC in the tear fluid has been shown to increase in an aqueous tear-deficient model following the instillation of a rebamipide ophthalmic suspension. ${ }^{22}$ Examination of the total mucin content in a rabbit eye model demonstrated that there was an increase in the corneal and conjunctival mucin content after the administration of a rebamipide ophthalmic solution. ${ }^{18}$

Rebamipide increased the secretion of both membraneassociated and secreted-type mucins through mucin production in the conjunctival goblet cells, and in the corneal epithelial cells. ${ }^{23-25}$ Although the lack of a complete understanding of ocular mucin expression led to the elimination of mucin deficiency as a definitive entity in dry eye syndrome, ${ }^{46}$ the increase of secretory mucin by rebamipide is related to tear film stability through the enhancement of mucin expression, ${ }^{48}$ which might show another aspect of dry eye syndrome.

\section{Conjunctival goblet cells}

Secreted-type mucin is produced and secreted by conjunctival goblet cells. A decrease in the goblet cell number, which has been reported in dry eye patients, is thought to be one of the causes of the onset and exacerbation of dry eye. ${ }^{49}$ Investigations of the effect of rebamipide on the conjunctival goblet cell count using impression cytology found that a rebamipide ophthalmic suspension increased goblet cell count in normal rabbits (Figure 2). ${ }^{50}$

\section{Corneal and conjunctival epithelial damage}

Based on the state of the tear fluid, dry eye is divided into an aqueous-deficient type and an evaporative type. ${ }^{51}$ In aqueousdeficient dry eye, the tear fluid supply from the lacrimal glands decreases and the tear exchange declines, leading to a deterioration in tear quality, such as high osmolality due to Sjögren's syndrome. ${ }^{51}$ Evaporative dry eye, on the other hand, is caused by decreased tear stability due to various factors. One factor behind decreased tear stability is related to the decreased lubrication of the ocular surface caused by the decreased mucin secretion. ${ }^{52}$

The effect of a rebamipide ophthalmic suspension on corneal epithelial damage due to aqueous deficiency was investigated using a rat model in which the exorbital lacrimal glands were removed. The findings demonstrated that rebamipide significantly improved the corneal epithelial damage. ${ }^{53}$ Urashima et al ${ }^{18}$ further examined the corneal and conjunctival epithelial damage in $\mathrm{N}$-acetylcysteine-treated rabbit eyes, which causes a mucin deficiency condition on the

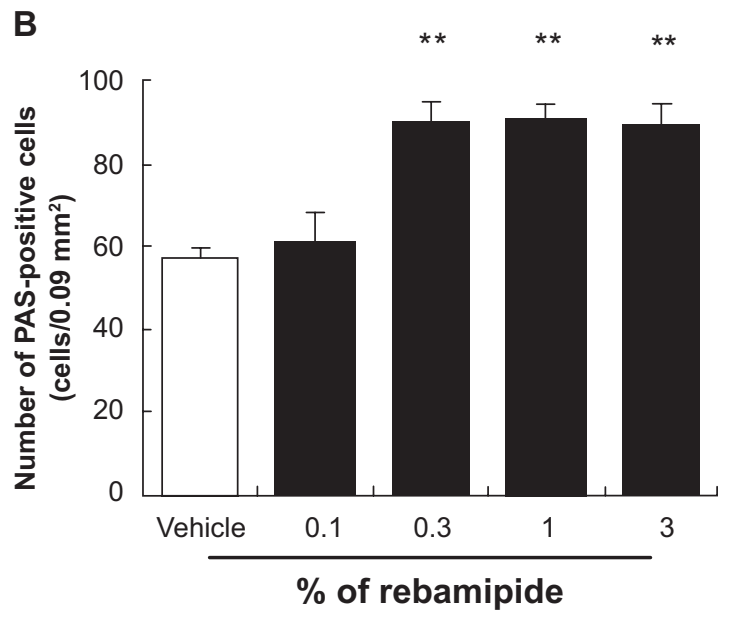

Figure 2 Effect of rebamipide on conjunctival goblet cells in rabbit.

Notes: (A) Photomicrographs showing PAS staining of filter paper containing PAS-positive cells after 15 days of treatment. Shown on the left is the vehicle-treated group; shown on the right is the 1\% rebamipide-treated group. (B) The effects of rebamipide on the number of PAS-positive cells in the conjunctiva. Mean \pm standard error ( $\mathrm{n}=7-8$ ). $* * P<0.0$ I versus vehicle (two-tailed Dunnett test). Reproduced from Urashima H, Okamoto T, Takeji Y, Shinohara H, Fujisawa S. Rebamipide increases the amount of mucinlike substances on the conjunctiva and cornea in the $\mathrm{N}$-acetylcysteine-treated in vivo model. Cornea. 2004;23(6):613-6I9. Promotional and commercial use of the material in print, digital or mobile device format is prohibited without the permission from the publisher Lippincott Williams \& Wilkins. Please contact journalpermissions@lww.com for further information. Copyright ( 2004. Wolters Kluwer Health. ${ }^{18}$

Abbreviation: PAS, periodic acid-Schiff reagent. 


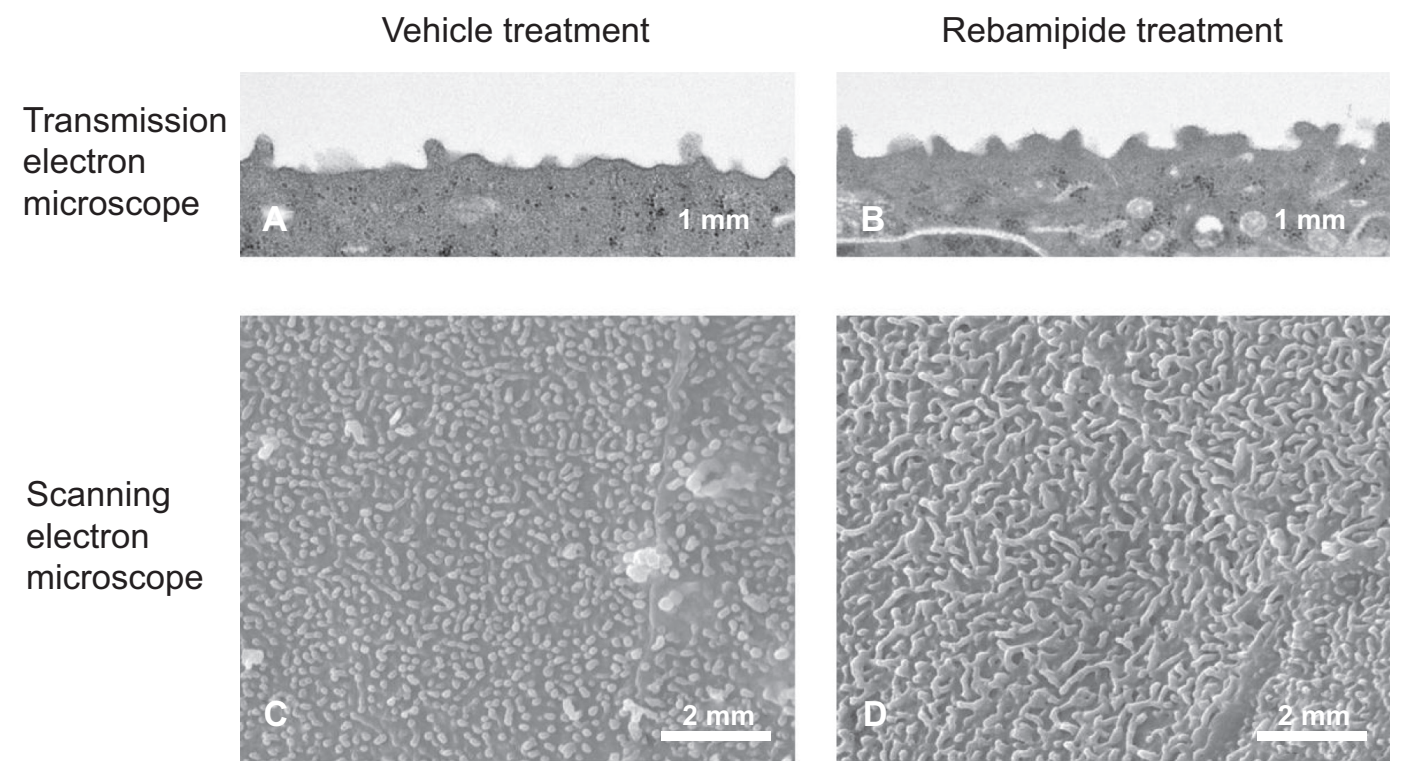

Figure 3 Effect of rebamipide on microscopic structure in rabbit cornea after the application of N-acetylcysteine.

Notes: These photographs show the effect of a rebamipide ophthalmic suspension on corneal and conjunctival damage in the mucin-removed rabbit eye model using $\mathrm{N}$-acetylcysteine. The fine structure of the corneal and conjunctival surface was examined using transmission and scanning electron microscopy. (A and C) Vehicle treatment for 2 weeks [(A) transmission electron microscope, (C) scanning electron microscope]. (B and D) Rebamipide treatment for 2 weeks [(B) transmission electron microscope, (D) scanning electron microscope]. Reproduced from Nakashima H, Urashima H, Takeji Y, Shinohara H. Therapeutic effect of rebamipide ophthalmic suspension of corneal and conjunctival damage in mucin-removed rabbit eye model. Atarashii Ganka. 2012;29:I I47-I I5I. Japanese. ${ }^{55}$ Copyright @ 2012.

ocular surface, and demonstrated that rebamipide significantly improved the corneal and conjunctival epithelial damage.

Microvilli on the corneal and conjunctival surface contribute to the stabilization of the tear fluid by serving as a scaffold for the localization of mucin. In dry eye patients, it has been reported that microvilli decrease and become irregular, with the decreases in tear stability occurring in conjunction with the microvilli decrease..$^{54} \mathrm{~A}$ further study that investigated the effect of rebamipide on corneal and conjunctival microvilli found that rebamipide inhibited the microvilli damage in a $\mathrm{N}$-acetylcysteine-treated rabbit model (Figure 3). ${ }^{55}$

Overall, these findings suggest that a rebamipide ophthalmic suspension is not only effective for corneal epithelial damage due to tear deficiency and decreased mucin, but also for restoration of the corneal and conjunctival surface microstructure that contribute to the tear stability.

\section{Inhibition of ocular surface inflammation}

In 2007, the Dry Eye Workshop published a definition of dry eye that stated, "it is accompanied by increased osmolarity of the tear film and inflammation of the ocular surface," which emphasizes the inflammatory response. ${ }^{51}$ It is thought that the high osmolarity of the tear film is due to decreased tear secretion and increased tear evaporation. Thus, the net result is that the increased osmolarity causes inflammation of the ocular surface.
In a study using cultured human corneal epithelial cells, ${ }^{56}$ rebamipide inhibited IL-6 and IL-8 production induced by tumor necrosis factor alpha (TNF- $\alpha$ ). These findings suggested that the mechanism responsible for the inhibition was the inhibition of NFKB activation. The tight junctions that exist between the corneal epithelial cells serve an important function as a barrier for deeper corneal tissue. A further study used electrical resistance and the expression of ZO-1, which is a tight junction protein, as indicators of the effect of rebamipide on the inflammatory cytokine-caused damage to tight junctions. ${ }^{51}$ The study results demonstrated that rebamipide had an inhibitory effect on TNF- $\alpha$-induced decreased electrical resistance, in addition to having an inhibitory effect on decreased ZO-1 (occluding) expression. Furthermore, this study also found that a rebamipide ophthalmic suspension reversed the decrease in ZO-1 expression in the corneal epithelium in a rat dry eye model in vivo. ${ }^{53}$

Recently, Ueta et al ${ }^{157}$ reported that rebamipide significantly attenuated the production of inflammatory cytokines and downregulated the messenger ribonucleic acid level of these cytokines. This study showed that the infiltration of eosinophils was suppressed in a dose-dependent manner. Based on Rebamipide's ability to modify epithelial cell functions, the authors suggested that this may open new strategies for treating human ocular surface inflammation, including allergic conjunctivitis and dry eye diseases. ${ }^{57}$ 
Table I Comparison of the clinical reports introduced in this review

\begin{tabular}{|c|c|c|c|c|}
\hline Author & Year & Study design & $\begin{array}{l}\text { Number } \\
\text { of patients }\end{array}$ & Target disease \\
\hline Kinoshita et $\mathrm{al}^{58}$ & 2012 & Randomized study & 308 & Dry eye patients \\
\hline Kinoshita et $\mathrm{al}^{59}$ & 2013 & Randomized study & 188 & Dry eye patients \\
\hline Koh et $\mathrm{al}^{60}$ & 2013 & Case series & 16 & Dry eye patients \\
\hline Takahashi et al ${ }^{62}$ & 2014 & Case series & 20 & Superior limbic keratoconjunctivitis \\
\hline Itakura et al ${ }^{63}$ & 2013 & Case series & 7 & Mild lagophthalmos \\
\hline Itakura et $\mathrm{al}^{64}$ & 2013 & Case series & 2 & Lid wiper epitheliopathy \\
\hline Kashima et $\mathrm{a}^{65}$ & 2012 & Case report & 1 & Persistent corneal erosion \\
\hline
\end{tabular}

\section{Rebamipide for clinical application}

It has not been long since the rebamipide ophthalmic suspension was launched; however, several reports on its clinical application have been published. ${ }^{58-65}$ The study design and patient numbers adopted in those papers are different, and those characteristics were summarized in Table 1. We will introduce these reports in this section.

\section{Rebamipide for dry eye syndrome}

Randomized, double-masked, placebo-controlled, multicenter, and parallel-group clinical trials for rebamipide treatment of the human ocular surface are currently being conducted. ${ }^{58,57}$ Kinoshita et $\mathrm{a}^{58}$ reported improvements of the fluorescein corneal staining score, lissamine green conjunctival staining score, and tear film break-up time score during their investigation of the rebamipide dose response, although they also found no significant difference for Schirmer's test values between the rebamipide and placebo groups. The authors reported that dry eye-related ocular symptom scores and the patients' overall treatment impression showed significant improvements in the $1 \%$ and $2 \%$ rebamipide groups. They confirmed the efficacy findings of their Phase II study results and demonstrated the superiority of $2 \%$ rebamipide to the $0.1 \%$ sodium hyaluronate. ${ }^{59}$ Additionally, in a subsequent Phase III study that compared $2 \%$ rebamipide with $0.1 \%$ sodium hyaluronate, Kinoshita et al ${ }^{59}$ demonstrated that there were no adverse events with either $2 \%$ rebamipide or $0.1 \%$ sodium hyaluronate similar to those associated with the benzalkonium chloride preservative. However, the authors considered the advantage of the rebamipide ophthalmic suspension, in that it does not contain preservatives, which can cause destabilization of the tear film, disruption of the corneal epithelium, a decrease of the density of the goblet cells, conjunctival squamous metaplasia with apoptosis, and damage to the deeper ocular tissues. The most frequently observed adverse event for the rebamipide ophthalmic suspension in the Kinoshita et al ${ }^{59}$ Phase III study was dysgeusia (bitter taste); however, this was only observed in $9.7 \%$ of the $2 \%$ rebamipide group.
There is a poor correlation between the symptoms and signs of dry eye, as only $57 \%$ of symptomatic patients have been found to exhibit objective signs of dry eye. Thus, an assessment of efficacy using subjective measures (symptoms), as well as objective measures (signs), is particularly important to perform in patients with dry eye.

Koh et $\mathrm{al}^{60}$ reported finding significant increases in the tear film break-up time, and there were significant upward curves from the baseline in terms of the total corneal higherorder aberrations, coma-like aberrations, and spherical-like aberrations after the application of rebamipide (Figure 4). In addition, their study demonstrated that rebamipide improved tear stability, possibly leading to improved optical quality. Therefore, an assessment of optical quality and the evaluation of the mucin level can provide supportive evidence regarding the importance of mucin for the quality of vision in patients with dry eye. The authors reported in another study that a significant increase in higher-order aberrations and forward light scatter occurred 1 minute after the instillation of rebamipide suspension, which returned to the preinstillation level. ${ }^{61}$

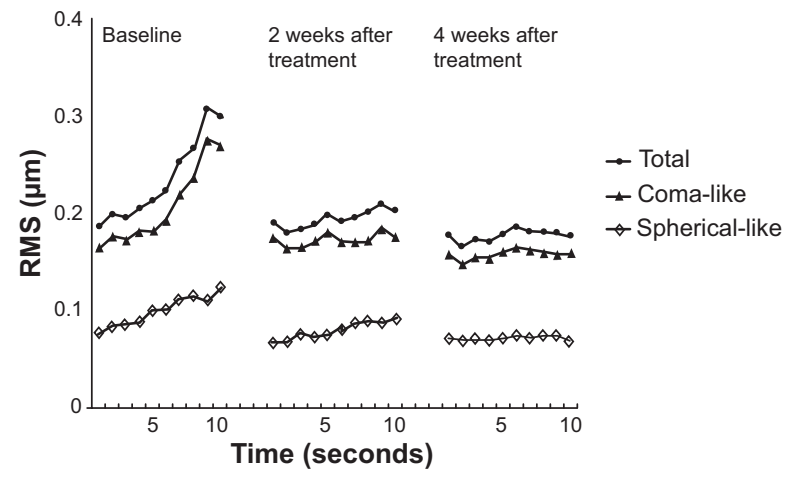

Figure 4 Sequential post blink changes in corneal HOAs, representing the mean data from 26 eyes analyzed with a $4 \mathrm{~mm}$ diameter pupil. RMS is the difference between the measured wavefront and the reference wavefront that includes spheres and astigmatism. Reproduced from Shizuka Koh, Yasushi Inoue, Toshiki Sugmimoto, et al. Effect of Rebamipide Ophthalmic Suspension on Optical Quality in the Short Break-up Time Type of Dry Eye. Cornea. 2013;32(9) I219-1223. Promotional and commercial use of the material in print, digital or mobile device format is prohibited without the permission from the publisher Lippincott Williams \& Wilkins. Please contact journalpermissions@ Iww.com for further information. ${ }^{60}$ Copyright (c) 2013. Wolters Kluwer Health.

Abbreviations: RMS, root mean square; Total, total HOAs; coma-like, coma-like aberrations; spherical-like, spherical-like aberrations; HOA, higher-order aberrations. 


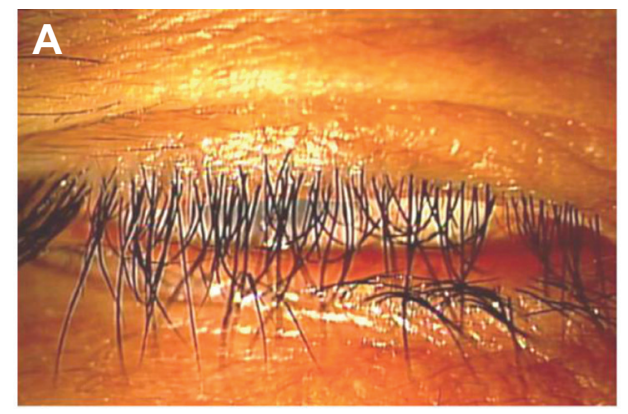

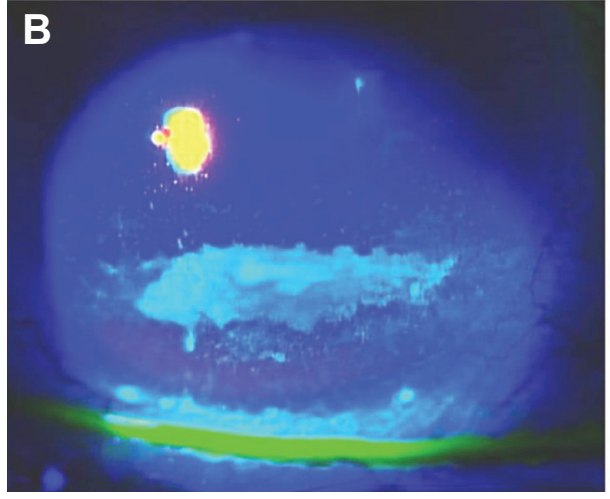

Before

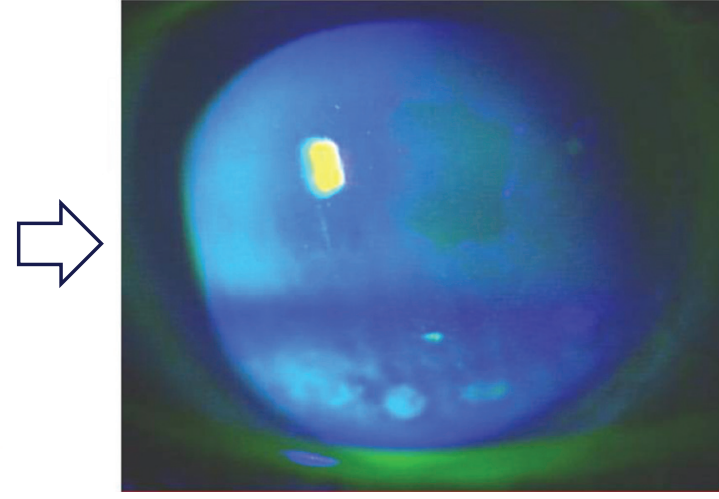

2 weeks after

Figure 5 Cornea of an 83-year-old female.

Notes: (A) The inferior cornea was slightly exposed with mild lagophthalmos after levator resection. (B) Fluorescein corneal staining showed that the inferior corneal erosions remarkably decreased 2 weeks after the administration of topical rebamipide eye drops. Copyright @ 2013 . Dove Medical Press. Reproduced from Itakura M, Itakura H, Kashima T, Akiyama H, Kishi S. Topical rebamipide improves the ocular surface in mild lagopthalmos. Clin Opthalmol. 2013;7:1333-1338.64

\section{Rebamipide for other ocular surface disorders}

As we have previously discussed, the administration of topical rebamipide improves the ocular surface in dry eye. However, several previous studies have found that topical rebamipide was not only effective for dry eye patients, but also for other ocular surface disorders with or without dry eye, such as superficial limbic keratopathy (SLK), lagophthalmos, lid wiper epitheliopathy, and persistent corneal erosion. ${ }^{62-65}$

Takahashi et $\mathrm{al}^{62}$ reported that thyroid eye disease patients with SLK who received topical rebamipide all showed improvements in SLK, which showed the complete disappearance of SLK after treatment in $84.8 \%$ of patients. The authors concluded that topical rebamipide may be a first-line treatment in such patients. ${ }^{62}$

One study ${ }^{64}$ examined seven eyes in seven cases with mild lagophthalmos (three cases after eyelid surgery, two cases of incomplete facial nerve palsy, and two cases of senile ectropion); the fluorescein corneal staining score and tear break-up time were significantly improved, and the scores for the ocular symptoms, such as eye pain, dryness, blurred vision, and foreign body sensations, also significantly improved. These results were similar to those of the clinical studies conducted with the dry eye patients (Figure 5). ${ }^{58,59}$ In another study, topical rebamipide was also shown to be effective for corneal and conjunctival disorders in lid wiper epitheliopathy. ${ }^{63}$ Although sodium hyaluronate and diquafosol are known to suppress inflammation, this study found that the antiinflammatory effect of rebamipide was greater than that of either of the drugs. Based on these findings, rebamipide eye drops were suggested as the first choice of treatment for patients with lid wiper epitheliopathy ${ }^{63}$ In another case report ${ }^{65}$ rebamipide was administered to Sjögren's syndrome patients who had erosion in the inferior cornea after surgical punctual occlusion. After application, the corneal erosion gradually improved and completely disappeared at 4 weeks after administration, even though other existing drugs had not been able to previously treat the erosion.

\section{Conclusion}

The rebamipide ophthalmic suspension was launched in January 2012 in Japan. Two years after this launch, published data have shown that this drug has been advantageous for the treatment of dry eye, as compared to other existing drugs currently being used, including lubricants. From our 
clinical experience of using this drug, the improvement of ocular surface conditions after its application is remarkable for the patients, especially in severe conditions. Overall, these findings confirm our belief that topical rebamipide may become the first drug of choice for some cases of dry eye syndrome. Moreover, we believe that this drug has a great potential to change the framework of treatment for ocular surface disorders in the future.

\section{Disclosure}

The authors report no conflicts of interest in this work.

\section{References}

1. Yamasaki K, Kanbe T, Chijiwa T, Ishiyama H, Morita S. Gastric mucosal protection by OPC-12759, a novel antiulcer compound, in the rat. Eur J Pharmacol. 1987;142(1):23-29.

2. Yamasaki K, Ishiyama H, Imaizumi T, Kanbe T, Yabuuchi Y. Effect of OPC-12759, a novel antiulcer agent, on chronic and acute experimental gastric ulcer, and gastric secretion in rats. Jpn J Pharmacol. 1989;49(4):441-448.

3. Uchida M, Tabusa F, Komatsu M, Morita S, Kanbe T, Nakagawa K. Studies on $2(1 \mathrm{H})$-quinolinone derivatives as gastric antiulcer active agents. 2-(4-Chlorobenzoylamino)-3-[2(1H)-quinolinon-4-yl]propi oni c acid and related compounds. Chem Pharm Bull (Tokyo). 1985;33(9):3775-3786.

4. Kleine A, Kluge S, Peskar BM. Stimulation of prostaglandin biosynthesis mediates gastroprotective effect of rebamipide in rats. Dig Dis Sci. 1993;38(8):1441-1449.

5. Naito Y, Yoshikawa T, Tanigawa T, et al. Hydroxyl radical scavenging by rebamipide and related compounds: electron paramagnetic resonance study. Free Radic Biol Med. 1995;18(1):117-123.

6. Yoshikawa T, Naito Y, Tanigawa T, Kondo M. Free radical scavenging activity of the novel anti-ulcer agent rebamipide studied by electron spin resonance. Arzneimittelforschung. 1993;43(3):363-366.

7. Nebiki H, Higuchi K, Arakawa T, et al. Effect of rebamipide on Helicobacter pylori infection in patients with peptic ulcer. Dig Dis Sci. 1998;43(9 Suppl):203S-206S.

8. Arakawa T, Kobayashi K. Quality of ulcer healing - a new concept to rank healed peptic ulcers. Gastroenterol Jpn. 1993;28 Suppl 5: $158-162$

9. Higuchi K, Arakawa T, Nebiki H, et al. Rebamipide prevents recurrence of gastric ulcers without affecting Helicobacter pylori status Dig Dis Sci. 1998;43(9 Suppl):99S-106S.

10. Arakawa T, Higuchi K, Fujiwara Y, et al. 15th anniversary of rebamipide: looking ahead to the new mechanisms and new applications. Dig Dis Sci. 2005;50 Suppl 1:S3-S11.

11. Sakurai K, Yamasaki K. Protective effect of rebamipide against hydrogen peroxide-induced hemorrhagic mucosal lesions in rat stomach. Jpn J Pharmacol. 1994;64(4):229-234.

12. Arakawa T, Higuchi K, Fujiwara Y, Watanabe T, Tominaga K, Sasaki E, Oshitani N, Yoshikawa T, Tarnawski AS. 15th anniversary of rebamipide: looking ahead to the new mechanisms and new applications. Dig Dis Sci. 2005;50 Suppl 1:S3-S11.

13. Matsuda T, Ohno S, Hirohata S, et al. Efficacy of rebamipide as adjunctive therapy in the treatment of recurrent oral aphthous ulcers in patients with Behçet's disease: a randomised, double-blind, placebo-controlled study. Drugs R D. 2003;4(1):19-28.

14. Ro JY, Kim JY, Kim KH. The inhibitory mechanism of rebamipide on the mediator release in the guinea pig lung mast cells activated with specific antigen-antibody reactions. Pharmacology. 2001;63(3):175-184.

15. Saad SY, Najjar TA, Al-Sohaibani MO. The effect of rebamipide on cisplatin-induced nephrotoxicity in rats. Pharmacol Res. 2000;42(1):81-86.
16. Hong KW, Kim KE, Rhim BY, Lee WS, Kim CD. Effect of rebamipide on liver damage and increased tumor necrosis factor in a rat model of endotoxin shock. Dig Dis Sci. 1998;43(9 Suppl):154S-159S.

17. Kishimoto S, Haruma K, Tari A, Sakurai K, Nakano M, Nakagawa Y. Rebamipide, an antiulcer drug, prevents DSS-induced colitis formation in rats. Dig Dis Sci. 2000;45(8):1608-1616.

18. Urashima H, Okamoto T, Takeji Y, Shinohara H, Fujisawa S. Rebamipide increases the amount of mucin-like substances on the conjunctiva and cornea in the $\mathrm{N}$-acetylcysteine-treated in vivo model. Cornea. 2004;23(6):613-619.

19. Watanabe T, Higuchi K, Hamaguchi M, et al. Rebamipide prevents delay of acetic acid-induced gastric ulcer healing caused by Helicobacter pylori infection in Mongolian gerbils. Dig Dis Sci. 2002;47(7):1582-1589.

20. Iijima K, Ichikawa $\mathrm{T}$, Okada S, et al. Rebamipide, a cytoprotective drug, increases gastric mucus secretion in human: evaluations with endoscopic gastrin test. Dig Dis Sci. 2009;54(7):1500-1507.

21. Mantelli F, Argüeso P. Functions of ocular surface mucins in health and disease. Curr Opin Allergy Clin Immunol. 2008;8(5):477-483.

22. Takeji Y, Nakashima H, Kagawa Y, Urashima H, Shinohara H. Effect of rebamipide ophthalmic suspension on capsaicin-induced corneal epithelial damage in rats. Atarashii Ganka. 2013;30:1309-1313. Japanese.

23. Ríos JD, Shatos M, Urashima H, Tran H, Dartt DA. OPC-12759 increases proliferation of cultured rat conjunctival goblet cells. Cornea. 2006;25(5):573-581.

24. Ríos JD, Shatos MA, Urashima H, Dartt DA. Effect of OPC-12759 on EGF receptor activation, p44/p42 MAPK activity, and secretion in conjunctival goblet cells. Exp Eye Res. 2008;86(4):629-636.

25. Takeji Y, Urashima H, Aoki A, Shinohara H. Rebamipide increases the mucin-like glycoprotein production in corneal epithelial cells. $J$ Ocul Pharmacol Ther. 2012;28(3):259-263.

26. Urashima H, Okamoto T, Takeji Y, Shinohara H, Fujisawa S. Rebamipide increases the amount of mucin-like substances on the conjunctiva and cornea in the $\mathrm{N}$-acetylcysteine-treated in vivo model. Cornea. 2004;23(6):613-619.

27. Ríos JD, Shatos M, Urashima H, Tran H, Dartt DA. OPC-12759 increases proliferation of cultured rat conjunctival goblet cells. Cornea. 2006;25(5):573-581.

28. Takeji Y, Urashima H, Aoki A, Shinohara H. Rebamipide increases the mucin-like glycoprotein production in corneal epithelial cells. J Ocul Pharamcol Ther. 2012;28(3):259-263.

29. Sakurai K, Osaka T, Yamasaki K. Rebamipide reduces recurrence of experimental gastric ulcers: role of free radicals and neutrophils. Dig Dis Sci. 2005;50 Suppl 1:S90-S96.

30. Iwai A, Iwashita E. Changes in colonic inflammation induced by dextran sulfate sodium (DSS) during short- and long-term administration of rebamipide. Dig Dis Sci. 1998;43(9 Suppl):143S-147S.

31. Fujioka T, Arakawa T, Shimoyama T, et al. Effects of rebamipide, a gastro-protective drug on the Helicobacter pylori status and inflammation in the gastric mucosa of patients with gastric ulcer: a randomized double-blind placebo-controlled multicentre trial. Aliment Pharmacol Ther. 2003;18 Suppl 1:146-152.

32. Haruma K, Ito M. Review article: clinical significance of mucosalprotective agents: acid, inflammation, carcinogenesis and rebamipide. Aliment Pharmacol Ther. 2003;18 Suppl 1:153-159.

33. Ishihara K, Komuro Y, Nishiyama N, Yamasaki K, Hotta K. Effect of rebamipide on mucus secretion by endogenous prostaglandinindependent mechanism in rat gastric mucosa. Arzneimittelforschung. 1992;42(12):1462-1466.

34. Ogino K, Hobara T, Ishiyama $\mathrm{H}$, et al. Antiulcer mechanism of action of rebamipide, a novel antiulcer compound, on diethyldithiocarbamateinduced antral gastric ulcers in rats. Eur J Pharmacol. 1992; 212(1):9-13.

35. Murakami K, Okajima K, Uchiba M, et al. Rebamipide attenuates indomethacin-induced gastric mucosal lesion formation by inhibiting activation of leukocytes in rats. Dig Dis Sci. 1997;42(2): $319-25$. 
36. Aihara M, Azuma A, Takizawa H, et al. Molecular analysis of suppression of interleukin- 8 production by rebamipide in Helicobacter pyloristimulated gastric cancer cell lines. Dig Dis Sci. 1998;43(9 Suppl): 174S-180S.

37. Murakami K, Okajima K, Uchiba M, et al. Rebamipide attenuates indomethacin-induced gastric mucosal lesion formation by inhibiting activation of leukocytes in rats. Dig Dis Sci. 1997;42(2):319-325.

38. Kim CD, Hong KW. Preventive effect of rebamipide on gastric lesions induced by ischemia-reperfusion in the rat. JPharmacol Exp Ther. 1995; 275(1):340-344.

39. Naito Y, Yoshikawa T, Iinuma S, et al. Local gastric and serum concentrations of rebamipide following oral administration to patients with chronic gastritis. Arzneimittelforschung. 1996;46(7):698-700.

40. Takemoto T, Obata H, Okazaki Y, et al. Dose-finding clinical study of efficacy of rebamipide on healing of acute gastritis or acute on chronic gastritis - comparison of two different doses in double-blind trial. Rinsho Seijin-byo. 1993;23:1163-1190.

41. Takemoto T, Yoshida Y, Takasugi T, et al. Dose-finding clinical study of efficacy of rebamipide (OPC-12759) on gastric ulcer healing (part 3)comparison of two different doses in double-blind trial. Rinsho Seijin-byo. 1989;19:753-775.

42. Naito Y, Yoshikawa T, Iinuma S, et al. Rebamipide protects against indomethacin-induced gastric mucosal injury in healthy volunteers in a double-blind, placebo-controlled study. Dig Dis Sci. 1998;43(9 Suppl): 83S-89S.

43. Fujiwara S, Morita Y, Toyonaga T, et al. A randomized controlled trial of rebamipide plus rabeprazole for the healing of artificial ulcers after endoscopic submucosal dissection. J Gastroenterol. 2011; 46(5):595-602.

44. Kobayashi M, Takeuchi M, Hashimoto S, et al. Contributing factors to gastric ulcer healing after endoscopic submucosal dissection including the promoting effect of rebamipide. Dig Dis Sci. 2012; 57(1):119-126.

45. Gipson IK, Argüeso P. Role of mucins in the function of the corneal and conjunctival epithelia. Int Rev Cytol. 2003;231:1-49.

46. Gipson IK. Distribution of mucins at the ocular surface. Exp Eye Res. 2004;78(3):379-388.

47. Shimazaki-Den S, Dogru M, Higa K, Shimazaki J. Symptoms, visual function, and mucin expression of eyes with tear film stability. Cornea. 2013;32:1211-1218.

48. Itoh $\mathrm{S}$, Itoh $\mathrm{K}$, Shinohara $\mathrm{H}$. Regulation of human corneal epithelial mucins by rebamipide. Curr Eye Res. 2014;39(2):133-141.

49. Argüeso P, Balaram M, Spurr-Michaud S, Keutmann HT, Dana MR, Gipson IK. Decreased levels of the goblet cell mucin MUC5AC in tears of patients with Sjögren syndrome. Invest Ophthalmol Vis Sci. 2002;43(4):1004-1011.

50. Urashima H, Takeji Y, Okamoto T, Fujisawa S, Shinohara H. Rebamipide increases mucin-like substance contents and periodic acid Schiff reagent-positive cells density in normal rabbits. J Ocul Pharmacol Ther. 2012;28(3):264-270.

51. The definition and classification of dry eye disease: report of the Definition and Classification Subcommittee of the International Dry Eye WorkShop (2007). Ocul Surf. 2007;5(2):75-92.
52. Sweeney DF, Millar TJ, Raju SR. Tear film stability: a review. Exp Eye Res. 2013;117:28-38.

53. Kimura K, Morita Y, Orita T, Haruta J, Takeji Y, Sonoda KH. Protection of human corneal epithelial cells from TNF- $\alpha$-induced disruption of barrier function by rebamipide. Invest Ophthalmol Vis Sci. 2013; 54(4):2572-2760

54. Cennamo GL, Del Prete A, Forte R, Cafiero G, Del Prete S, Marasco D. Impression cytology with scanning electron microscopy: a new method in the study of conjunctival microvilli. Eye (Lond). 2008; 22(1):138-143.

55. Nakashima H, Urashima H, Takeji Y, Shinohara H. Therapeutic effect of rebamipide ophthalmic suspension of corneal and conjunctival damage in mucin-removed rabbit eye model. Atarashii Ganka. 2012;29:1147-1151. Japanese.

56. Tanaka H, Fukuda K, Ishida W, Harada Y, Sumi T, Fukushima A. Rebamipide increases barrier function and attenuates TNF $\alpha$-induced barrier disruption and cytokine expression in human corneal epithelial cells. Br J Ophthalmol. 2013;97(7):912-916.

57. Ueta M, Sotozono C, Yokoi N, Kinoshita S. Rebamipide suppresses PolyI: C-stimulated cytokine production in human conjunctival epithelial cells. J Ocul Pharmacol Ther. 2013;29(7):688-693.

58. Kinoshita S, Awamura S, Oshiden K, Nakamichi N, Suzuki H, Yokoi N; Rebamipide Ophthalmic Suspension Phase II Study Group. Rebamipide (OPC-12759) in the treatment of dry eye: a randomized, doublemasked, multicenter, placebo-controlled phase II study. Ophthalmology. 2012;119(12):2471-2478

59. Kinoshita S, Oshiden K, Awamura S, Suzuki H, Nakamichi N, Yokoi N; Rebamipide Ophthalmic Suspension Phase 3 Study Group. A randomized, multicenter phase 3 study comparing 2\% rebamipide (OPC-12759) with $0.1 \%$ sodium hyaluronate in the treatment of dry eye. Ophthalmology. 2013;120(6):1158-1165.

60. Koh S, Inoue Y, Sugmimoto T, Maeda N, Nishida K. Effect of rebamipide ophthalmic suspension on optical quality in the short break-up time type of dry eye. Cornea. 2013;32(9):1219-1223.

61. Koh S, Maeda N, Ikeda C, et al. Effect of instillation of eyedrops for dry eye on optical quality. Invest Ophthalmol Vis Sci. 2013; 54(7):4927-4933.

62. Takahashi Y, Ichinose A, Kakizaki H. Topical rebamipide treatment for superior limbic keratoconjunctivitis in patients with thyroid eye disease. Am J Ophthalmol. 2014;157(4):807-812.

63. Itakura H, Kashima T, Itakura M, Akiyama H, Kishi S. Topical rebamipide improves lid wiper epitheliopathy. Clin Ophthalmol. 2013; 7:2137-2141.

64. Itakura M, Itakura H, Kashima T, Akiyama H, Kishi S. Topical rebamipide improves the ocular surface in mild lagophthalmos. Clin Ophthalmol. 2013;7:1333-1338.

65. Kashima T, Akiyama H, Miura F, Kishi S. Resolution of persistent corneal erosion after administration of topical rebamipide. Clin Ophthalmol. 2012;6:1403-1406.
Clinical Ophthalmology

\section{Publish your work in this journal}

Clinical Ophthalmology is an international, peer-reviewed journal covering all subspecialties within ophthalmology. Key topics include: Optometry; Visual science; Pharmacology and drug therapy in eye diseases; Basic Sciences; Primary and Secondary eye care; Patient Safety and Quality of Care Improvements. This journal is indexed on Submit your manuscript here: http://www.dovepress.com/clinical-ophthalmology-journal
Dovepress

PubMed Central and CAS, and is the official journal of The Society of Clinical Ophthalmology (SCO). The manuscript management system is completely online and includes a very quick and fair peer-review system, which is all easy to use. Visit http://www.dovepress.com/ testimonials.php to read real quotes from published authors. 